\title{
Pendekatan Saintifik Menggunakan Software Graphmatica untuk Menumbuhkan Kemampuan Komunikasi Matematika
}

\author{
Widiawati, Indah Widyaningrum
}

STKIP Muhammadiyah Pagaralam, Indonesia

Correspondence: \widiawati141@gmail.com

\begin{tabular}{|c|c|}
\hline Article Info & Abstract \\
\hline $\begin{array}{l}\text { Article History } \\
\text { Received : 03-07-2019 } \\
\text { Revised : 13-11-2019 } \\
\text { Accepted : 30-11-2019 } \\
\text { Keywords: } \\
\text { Scientific approach; } \\
\text { Graphmatica software; } \\
\text { Mathematical } \\
\text { communication skill }\end{array}$ & $\begin{array}{l}\text { The purpose of this study was to find out the mathematical communication skills of } \\
\text { students during the scientific approach was applied using graphmatica software on } \\
\text { function graph material in college. This research was an experimental study in the } \\
\text { category of one group pretest posttest design involving } 30 \text { first semester students of } \\
\text { mathematics education study program at STKIP Muhammadiyah Pagaralam. The results } \\
\text { showed that students' mathematical communication skills during the applied scientific } \\
\text { approach using graphmatica software on function graph material were classified as very } \\
\text { good. This means that the use of graphmatica software through the scientific approach } \\
\text { can build students' mathematical communication skills. Through the learning process } \\
\text { based on a scientific approach consisting of observing, quetioning, associating, } \\
\text { experimenting, and networking, students' mathematical communication skills both } \\
\text { verbally and in writing are classified as very good. For this reason, these activities have a } \\
\text { positive influence on students. Beside building students' mathematical communication } \\
\text { this approach also influence students' learning outcomes. Better the mathematical } \\
\text { communication skills, better the learning outcomes. Therefore, building mathematical } \\
\text { communication skills is very important in learning especially in learning through a } \\
\text { scientific approach using graphmatica software. The use of graphmatica software can be } \\
\text { used in other course such as calculus courses. So, graphmatica software can be used in } \\
\text { other course so that it is not limited according to the design of the material to be } \\
\text { implemented }\end{array}$ \\
\hline
\end{tabular}

\section{PENDAHULUAN}

Pentingnya belajar grafik fungsi Aljabar di perguruan tinggi adalah menyediakan suatu konteks yang mana mahasiswa dapat melihat bahwa mata kuliah bidang Matematika merupakan mata kuliah yang saling berhubungan. Misalnya, untuk belajar mata kuliah Kalkulus harus memahami grafik fungsi. Hal ini sejalan dengan hasil penelitian yang menyatakan bahwa mahasiswa mengalami kesulitan dalam memahami konsep fungsi terutama menggambar grafik fungsi pada mata kuliah Kalkulus 1 [1]. Selain itu, pencapaian prestasi mahasiswa pada setiap mata kuliah di pengaruhi oleh faktor yang sangat dominan yaitu penguasaan mahasiswa terhadap kemampuan dasar Matematika diantaranya Aljabar [2]. Oleh karena itu, materi grafik fungsi Aljabar sangat penting untuk dipelajari oleh mahasiswa. Pentingnya materi tersebut menuntut mahasiswa untuk bisa memahaminya agar tidak menemukan kesulitan pada materi yang lainnya.

Mahasiswa mengalami kesulitan dalam menggambar grafik fungsi. Hal ini dapat dilihat dari kesalahan-kesalahan yang dilakukan mahasiswa seperti tidak membuat titik koordinat dengan tepat sehingga tidak bisa menggambar grafik [3]. Sejalan juga dengan hasil penelitian yang mengatakan bahwa mahasiswa belum memahami cara menggambar grafik fungsi [4]. Selain itu, mahasiswa tidak dapat menerapkan konsep dasar yang dimiliki ketika permasalahan dalam menggambar koordinat kartesius disajikan dalam bentuk abstrak [5]. Untuk itu, diperlukan pemahaman konsep mahasiswa terhadap materi tersebut. Sesuai dengan tuntutan kurikulum Matematika bahwa mahasiswa harus mempunyai pemahaman konsep terhadap materi yang diberikan melalui komunikasi pembelajaran Matematika. 
Komunikasi Matematika dalam pembelajaran Matematika sangat penting. Hal ini dikarenakan, komunikasi Matematika merupakan salah satu kompetensi yang harus dikuasai setelah belajar Matematika [6]. Komunikasi Matematika bukanlah kemampuan yang sudah ada, tetapi kemampuan itu perlu dikembangkan dalam pembelajaran [7]. Selain itu, kemampuan komunikasi Matematika dapat membantu proses penyusunan pikiran, menghubungkan gagasan dengan gagasan lain sehingga dapat mengisi hal-hal yang kurang dalam seluruh jaringan gagasan peserta didik[8]. Beberapa kriteria yang dipakai dalam melihat seberapa besar kemampuan peserta didik dalam memiliki kemampuan komunikasi Matematika pada pembelajaran Matematika adalah sebagaimana yang dikemukakan oleh NCTM, yaitu: a) kemampuan mengekspresikan ide-ide Matematika melalui lisan, tulisan, dan mendemonstrasikannya serta menggambarkannya secara visual; b) kemampuan memahami, menginterpretasikan, dan mengevaluasi ideide Matematika baik secara lisan maupun dalam bentuk visual lainnya; dan c) kemampuan menggunakan istilah, notasi Matematika dan struktur-strukturnya untuk menyajikan ide, menggambarkan hubungan dan model situasi[9]. Sedangkan indikator-indikator kemampuan komunikasi Matematika yang dapat dikembangkan menurut Sumarmo, yakni: a) menyatakan suatu situasi, gambar, diagram, atau benda nyata ke dalam bahasa, simbol, ide, atau model matematik; b) menjelaskan ide, situasi, dan relasi Matematika secara lisan atau tulisan; c) mendengarkan, berdiskusi, dan menulis tentang Matematika; d) membaca dengan pemahaman suatu representasi Matematika tertulis; dan e) mengungkapkan kembali suatu uraian atau paragraf Matematika dalam bahasa sendiri[10]. Dalam komunikasi tersebut terjadi suatu hubungan atau interaksi baik antara pendidik dengan peserta didik maupun peserta didik dengan peserta didik dalam hal menyampaikan ide Matematika yang dilakukan dalam diskusi. Untuk itu, pendidik harus mampu memilih suatu pendekatan pembelajaran yang tepat. Salah satu pendekatan pembelajaran yang dapat digunakan adalah pendekatan saintifik.

Pendekatan Saintifik dalam pembelajaran dapat mendorong peserta didik terlibat secara aktif dalam proses belajar [11]. Ide pendekatan saintifik adalah untuk mendorong pembelajaran Matematika dalam konteks ilmiah dan kegiatan peserta didik [12]. Adanya ide tersebut, penggunaan software sangat berguna untuk proses pemahaman mahasiswa terhadap materi yang diberikan seperti software graphmatica. Penggunaan dan pemanfaatan software-software Matematika seperti graphmatica merupakan upaya yang dapat dilakukan untuk menyiapkan calon pendidik Matematika [13]. Penggunaan software graphmatica memberikan pengaruh yang baik terhadap prestasi belajar mahasiswa pada materi program linier [14]. Mahasiswa dapat mengkombinasikan ide-ide yang masuk menjadi suatu pengetahuan yang bermakna.

Berdasarkan uraian di atas, tujuan dari penelitian ini adalah untuk mengetahui kemampuan komunikasi Matematika mahasiswa selama diterapkan pendekatan saintifik menggunakan software graphmatica pada materi grafik fungsi di Perguruan Tinggi.

\section{METODE PENELITIAN}

Penelitian ini dilakukan pada mahasiswa semester satu program studi pendidikan Matematika di STKIP Muhammadiyah Pagaralam yang berjumlah 30 orang. Jenis penelitian yang digunakan penelitian eksperimen untuk menerapkan pendekatan saintifik pada pembelajaran Matematika dengan kategorione group pretest postest design. Dalam desain ini sekelompok sampel dipilih dari populasi tertentu sehingga didapatkan satu kelompok atau satu kelas (A). Selanjutnya kelas tersebut diberikan tes awal (O) untuk melihat kemampuan awal yang dimiliki oleh mahasiswa mengenai materi grafik fungsi dan diberikan perlakuan berupa pembelajaran dengan penerapan pendekatan saintifik menggunakan sofware graphmatica (X). Kemudian diberikan tes akhir (O) untuk melihat hasil belajar mahasiswa setelah diberikan pembelajaran tersebut. Setelah perlakuan pembelajaran, diteliti dampak yang muncul pada subjek penelitian sebagai akibat dari perlakuan pembelajaran yaitu kemampuan komunikasi Matematika mahasiswa. Pola desain tersebut, dapat dilihat pada tabel 1. 
Numerical: Jurnal Matematika dan Pendidikan Matematika, Vol. 3 No. 2 Desember 2019, 95-104

Widiawati, Indah Widyaningrum

Tabel 1. One Group Pretest Postest Design[15]

\begin{tabular}{ccc}
\hline Pretes & Variabel Terikat & Postes \\
\hline $\mathrm{O}_{1}$ & $\mathrm{X}$ & $\mathrm{O}_{2}$ \\
\hline
\end{tabular}

Selama melakukan penelitian, beberapa teknik pengumpulan data seperti rekaman video, Lembar Aktivitas Mahasiswa (LAM), wawancara, dan catatan lapangan dikumpulkan dan dianalisis. Analisis hasil rekaman video, LAM, wawancara, dan catatan lapangan dilakukan secara kualitatif.

\section{HASIL DAN PEMBAHASAN}

Dalam pembelajaran pada materi grafik fungsi, mahasiswa dibagi dalam setiap kelompok berjumlah5orang. Mahasiswa mengerjakan Lembar Kegiatan Mahasiswa (LKM) yang terdiri dari 3 LKM masing-masing dengan 3 fungsi berbeda yaitu fungsi persamaan linear, fungsi polinom, dan fungsi akar menggunakan software graphmatica melalui pendekatan saintifik dengan tujuan agar mahasiswa mengetahui cara membuat grafik fungsi secara manual. Pembelajaran dengan pendekatan saintifik terdiri dari kegiatan mengamati, menanya, menalar, mencoba, dan membentuk jejaring (menyimpulkan, menyajikan, mengkomunikasikan) serta menciptakan sebagai hasil akhir. Dari kegiatan-kegiatan saintifik tersebut dapat menumbuhkan kemampuan komunikasi Matematika mahasiswa baik secara lisan maupun tulisan. Hal ini dapat dilihat pada kegiatan-kegiatan mahasiswa selama mengerjakan LKM. Di mana, mahasiswa begitu antusias dalam belajar dengan melakukan komunikasi-komunikasi antar sesama mahasiswa dan juga dosen sehingga permasalahan dapat terselesaikan dengan baik. Terjadinya komunikasi-komunikasi tersebut menunjukkan bahwa kegiatan-kegiatan pada pembelajaran menggunakan pendekatan saintifik dapat menumbuhkembangkan kemampuan komunikasi Matematika mahasiswa karena proses pembelajarannya dapat mengajak mahasiswa untuk melakukan komunikasi dan adanya software graphmatica dapat mendorong mahasiswa untuk melakukan komunikasi tersebut. Proses pembelajaran ini pada setiap LKM dapat diuraikan sebagai berikut.

Pada LKM yang pertama, mahasiswa menyelesaikan permasalahan mengenai cara membuat grafik persamaan linier dalam bentuk $a x+b y=c$. Untuk menyelesaikan permasalahan tersebut, mahasiswa menggunakan software graphmatica dalam kelompoknya dengan mengikuti LKM yang telah diberikan. Mahasiswa membuat sendiri fungsi persamaan linier sesuai dengan bentuknya untuk diinput. Setelah mereka menginput fungsi tersebut, mereka menentukan hubungan antara grafik dengan point tablesyang muncul pada software graphmatica. Untuk menentukan hubungan tersebut, mahasiswa melakukan kegiatan mengamati yaitu mengamati grafik dan point tables yang tampil pada software graphmatica seperti yang terlihat pada gambar 2.

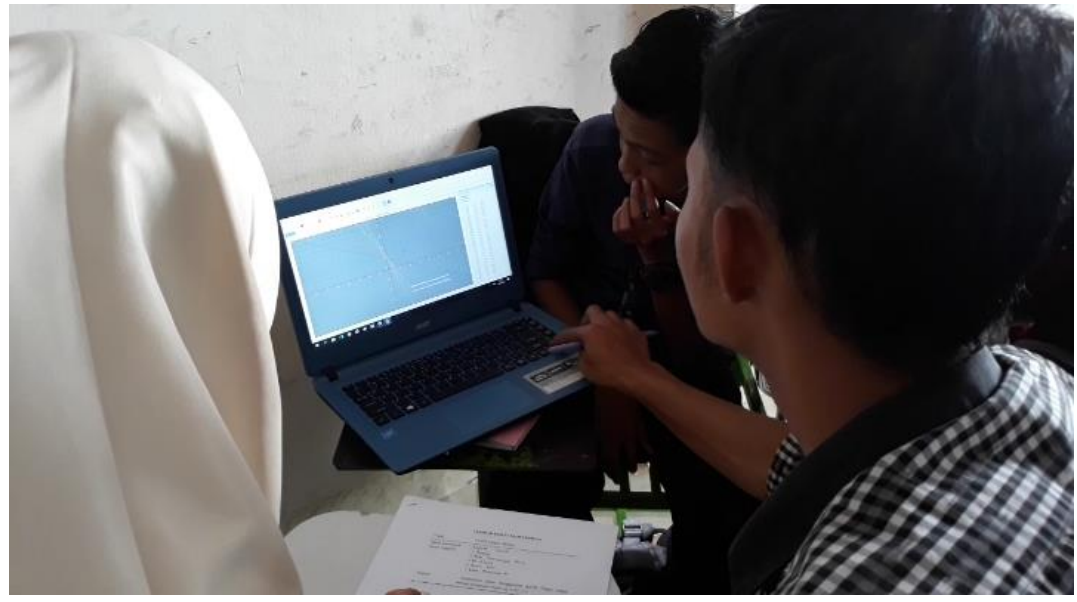

Gambar 2. Mahasiswa Mengamati Grafik dan Point Tables pada Fungsi Persamaan Linier 
Dari gambar 2 terlihat bahwa mahasiswa sedang mengamati grafik dan point tables pada software graphmatica berdasarkan fungsi yang mereka input sendiri. Hal ini dilakukan untuk mengetahui hubungan antara grafik dengan point tables. Dalam menentukan hubungan itu, terjadi percakapan antar mahasiswa dengan dosen melalui kegiatan menanya.

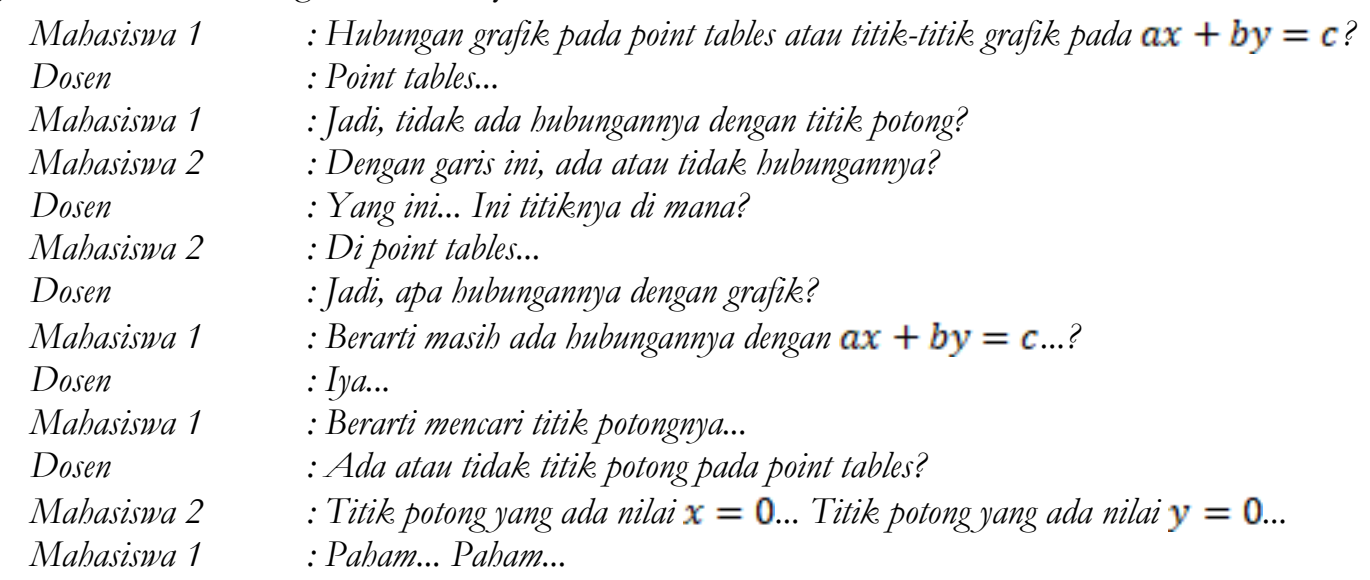

Berdasarkan percakapan di atas menunjukkan bahwa mahasiswa masih bingung untuk menjelaskan hubungan antara grafik dengan point tables. Setelah saling bertanya, mereka mengerti. Dari kegiatan menanya tersebut, mahasiswa melakukan kegiatan menalar sehingga dapat memperoleh pemahaman bahwa dalam point tables terdapat titik potong baik terhadap sumbu $y$ maupun sumbu $x$. Hal ini lebih diperdalam lagi kebenarnya oleh mahasiswa dengan melakukan kegiatan mencoba. Dalam kegiatan mencoba ini, mahasiswa mencoba untuk menginput beberapa fungsi persamaan linier. Setelah mereka menginput beberapa fungsi tersebut, mereka selalu menemukan nilai 0 baik pada nilai $x$ maupun nilai $y$ atau dengan kata lain titik potong terhadap sumbu $x$ dan $y$. Ini berarti bahwa mahasiswa telah menemukan bahwa point tables merupakan kumpulan dari titik-titik pembentuk grafik $a x+b y=c$ yang diantaranya merupakan titik potong pembentuk grafik. Dengan demikian, mahasiswa telah mengetahui hubungan antara grafik dengan point tables.

Kemudian mahasiswa melakukan kegiatan membentuk jejaring. Pada kegiatan ini, mahasiswa dapat menyimpulkan, menyajikan, dan mengkomunikasikan. Dalam menyimpulkan, mahasiswa dapat menyimpulkan mengenai cara membuat grafik persamaan linier. Dengan mengetahui hubungan antara grafik dan point tables, mahasiswa dapat menyimpulkan bahwa untuk membuat grafik persamaan linier dapat dilakukan dengan cara menentukan titik-titik potongnya. Selain itu, ada juga yang menjelaskan bahwa untuk membuat grafik tersebut dengan cara mensubstitusi nilai $x$ sehingga nantinya ditemukan nilai $y$ dan ditemukan beberapa titik $(x, y)$ seperti pada gambar 3 .

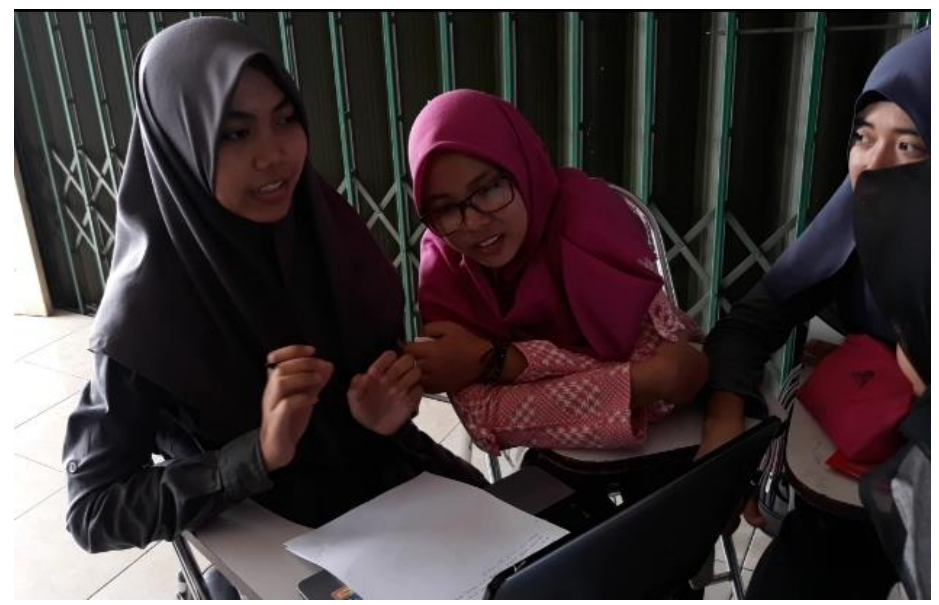

Gambar 3. Mahasiswa Menjelaskan Cara Membuat Grafik 


\section{Fungsi $a x+b y=c$}

Pada gambar 3 terlihat mahasiswa sedang menjelaskan cara menggambar grafik fungsi $a x+b y=c$ melalui percakapan yang terjadi antara mahasiswa dengan dosen. Pencakapan tersebut dapat diuraikan sebagai berikut.
Dosen
: Jadi, apa kesimpulannya?
Mahasiswa 3
: Kesimpulannya... grafik menunjukkan gambar titik-titik pada point tables. Sedangkan point tables hanya menunjukkan titik-titik pada garis grafik tersebut...
Dosen : Jadi, bagaimana cara membuat grafiknya tanpa menggunakan software?
Mahasiswa 3 : Cari nilai $x$ dan $y$, setelah dapat nilai $x$ baru cari nilai y... Lalu tentukan titik-titik pada grafik, terus tarik, garis...

Dari percakapan di atas, mahasiswa dapat menyimpulkan bahwa cara membuat grafik fungsi $a x+b y=c$ adalah dengan menentukan nilai $x$ dan $y$. Setelah itu, menentukan titik-titik pada grafik dan menghubungkan titik-titik tersebut menjadi garis. Dengan kata lain, untuk fungsi persamaan linier akan selalu menghasilkan grafik berupa garis lurus.

Setelah menyimpulkan, mahasiswa harus menyajikan hasil yang diperoleh dalam LKM yang telah diberikan untuk dikomunikasikan dalam suatu presentasi. Hal ini dilakukan untuk mengetahui kebenaran dari hasil yang diperoleh. Dalam kegiatan ini, mahasiswa dapat mengetahui kebenaran jawaban yang telah mereka temukan. Dengan melalui kegiatan-kegiatan saintifik tersebut, mahasiswa dituntut untuk dapat menciptakan. Di sini, mahasiswa dapat membuat soal sendiri beserta penyelesaian grafiknya.

Pada LKM yang kedua, mahasiswa menyelesaikan permasalahan mengenai cara membuat grafik fungsi polinom dalam bentuk $y=a_{n} x^{n}+a_{n} x^{n-1}+\cdots+a_{1} x+a_{0}$. Sama halnya seperti pada LKM pertama bahwa mahasiswa menginput fungsi sendiri pada software graphmatica dalam bentuk fungsi polinom.Mahasiswa melakukan kegiatan mengamati dengan mengamati grafik fungsi polinom dengan point tables untuk mengetahui hubungan antara keduanya. Untuk mengetahui hubungan tersebut, terjadilah percakapan antara dosen dan mahasiswa melalui kegitan menanya.

\section{Mahasiswa $4 \quad$ : Kalau pangkeat tertingginya 2, seperti ini...? \\ Dosen $\quad$ : Iya, bentuknya pasti parabola karena pangkat tertinggi 2 berarti persamaan kuadrat... \\ Mahasiswa $5 \quad$ : Berarti semakin tinggi pangkatnya, semakin tinggi grafiknya...? \\ Dosen : : Tergantung fungsinya...}

Dari percakapan di atas, mahasiswa dapat menjelaskan bahwa semakin tinggi pangkatnya atau nilainya, maka akan semakin menaik/meninggi grafiknya. Dengan kegiatan menalar, mahasiswa dapat menentukan hubungan antara grafik fungsi polinom dengan point tables. Hubungan yang mereka dapatkan adalah berdasarkan perhitungan yang telah diamati dari semakin tingginya pangkat dan nilai yang mempengaruhi bentuk grafik, maka nilai-nilai $x$ dan $y$ sebagai titik pembentuk grafik. Hal ini dilakukan berulang-ulang pada kegiatan mencoba untuk memastikan dugaan yang telah mahasiswa temukan. Faktanya dugaan mereka memang benar. Setelah itu, mahasiswa melakukan kegiatan membentu jejaring dengan memberikan kesimpulan, menyajikan hasil dalam LKM, dan mempresentasikan hasil LKM. Hasil penyelesaian LKM, mahasiswa dapat menjelaskan cara membuat grafik fungsi polinom.

Mahasiswa dapat menjelaskan grafik fungsi polinom dan cara membuat grafiknya baik menggunakan software maupun tanpa software. Cara membuat grafik tanpa menggunakan software sama seperti pada persamaan linier dengan menentukan nilai $x$ dan $y$. Setelah didapatkan nilai $x$ dan $y$ yang berupa titik-titik, maka titik-titik itu dibuat pada grafik dan dihubungkan satu sama lain sehingga terbentuklah grafik fungsinya. Hal ini sesuai dengan jawaban LKM yang diselesaikan oleh mahasiswa yang merupakan hasil dari mahasiswa dalam membuat soal sendiri dan penyelesaiannya. Penyelesaian yang dilakukan dengan mensubstitusi nilai $x$ agar ditemukan nilai $y$ seperti pada gambar 5 . 


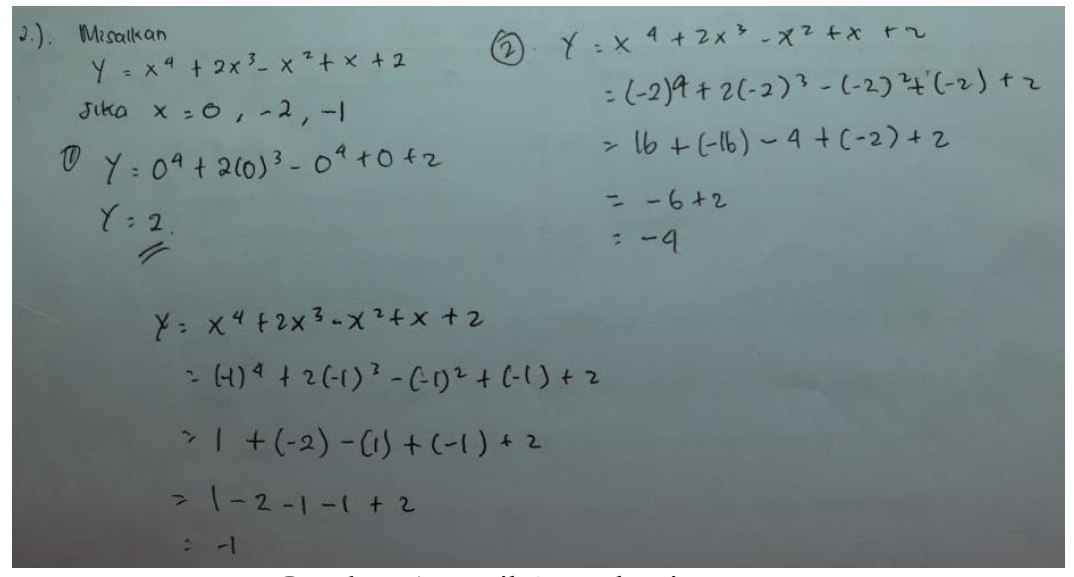

Gambar 5. Hasil Penyelesaian LKM

Berdasarkan gambar 5, dapat dikatakan bahwa dalam membuat grafik fungsi polinom bisa dengan menentukan nilai $y$. Hasil dari nilai-nilai tersebut merupakan titik-titik pembentuk grafik. Dengan demikian, menentukan nilai $x$ dan $y$ menjadi langkah awal dalam membuat grafik fungsi polinom. Hal ini dapat diterapkan oleh mahasiswa dengan menciptakan soal sendiri dan penyelesaiannya.

Pada LKM yang ketiga, mahasiswa menyelesaikan permasalahan mengenai cara membuat grafik fungsi akar dalam bentuk $y=\sqrt[n]{a x+b}$. Langkah-langkah yang dilakukan sama seperti pada kedua LKM sebelumnya. Pada kegiatan mengamati, mahasiswa mengamati grafik fungsi akar dengan point tables yang ada pada software graphmatica. Dalam hal ini, terjadi percakapan antara sesama mahasiswa dan dosen seperti gambar 6 berikut.

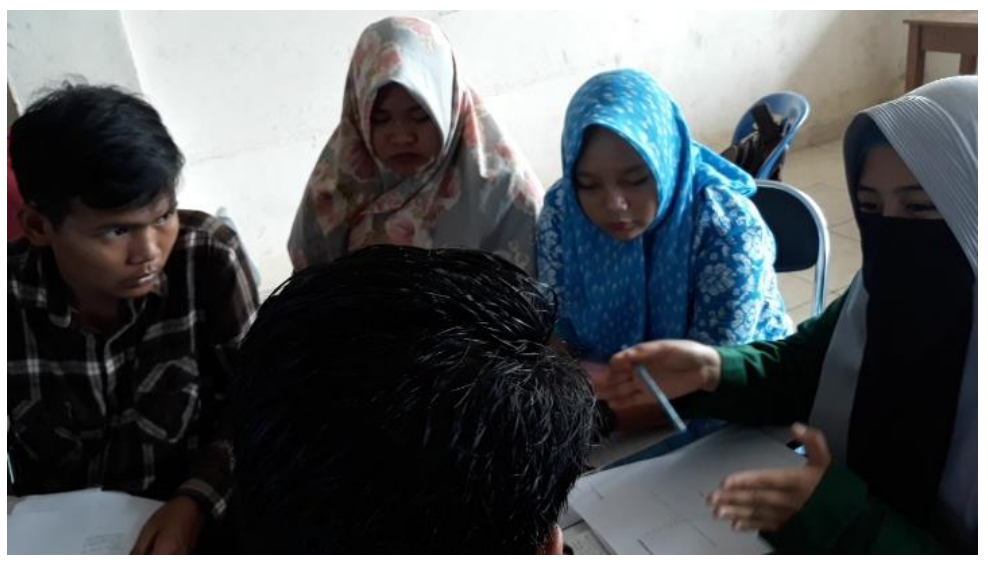

Gambar 6. Percakapan dalam Menyelesaikan LKM
Mahasiswa 6
Mahasiswa 7
Dosen
: Bagaimana cara membuat akarmya?
Mahasiswa 8
: Seperti contoh tadi, akar diubah menjadi bentuk pangkat...
:Iya...
: Hubungan antara grafik dengan point tables tersebut adalab untuk memberikan denah yang ada pada grafik seperti contoh...

Dari gambar 6 dan percakapan di atas, mahasiswa bingung untuk menginput fungsi akar. Setelah saling berkomunikasimelalui kegiatan menanya, mereka jadi mengerti bahwa akar harus diubah terlebih dahulu kebentuk akar dan point tables adalah pembentuk grafik. Setelah itu, dengan kegiatan menalar mahasiswa dapat menjelaskan hubungan antara grafik dengan point tables. Dimana, hubungannya adalah bahwa grafik terbentuk dari titik-titik pada point tables. Selain itu, ada juga yang mengatakan jika $x$ bernilai negatif maka $y$ akan bernilai tak terhingga. Artinya,semakin kecil harga $x$ yang bernilai negatif maka nilai $y$ semakin tak terhingga. Dengan demikian, melalui kegiatan membentuk jejaring mahasiswa dapat menyimpulkan bahwa cara membuat grafik fungsi akar dapat dilakukan dengan menentukan nilai $x$ dan $y$. Hal ini juga dapat 
dilihat dari penyelesaian fungsi akar yang mahasiswa tentukan sendiri fungsinya dari hasil menciptakan pada gambar 7.

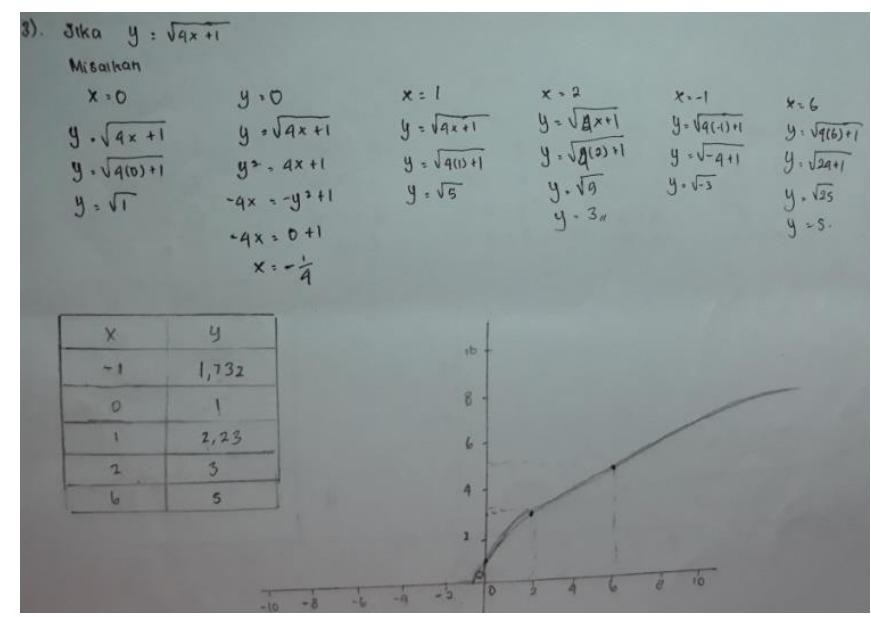

Gambar 7. Hasil Penyelesaian Grafik Fungsi Akar

Pada gambar 7, mahasiswa dapat menentukan fungsi akar sendiri dan menyelesaikannya. Cara yang mereka lakukan dengan menentukan nilai $x$ dan $y$. Kemudian titik-titik yang dihasilkan dari nilai-nilai tersebut dibuat dalam grafik.

Berdasarkan hasil analisis di atas, mahasiswa dapat menentukan cara membuat grafik fungsi secara manual dengan menggunakan software graphmatica melalui pendekatan saintifik. Hal tersebut dikarenakan mahasiswa melakukan komunikasi Matematika baik secara lisan maupun tulisan dalam pembelajaran. Komunikasi Matematika ini tumbuh selama kegiatan pembelajaran melalui pendekatan saintifik menggunakan software graphmatica. Dengan menggunakan software graphmatica, mahasiswa dapat mengamati grafik fungsi yang mereka input sendiri pada software tersebut. Dari mengamati, mahasiswa dapat bertanya satu sama lain baik dengan sesama mahasiswa maupun dosen tentang permasalahan yang kurang dipahami atau membingungkan. Dengan saling bertanya satu sama lain, mahasiswa dapat berpikir untuk memperoleh suatu dugaan terhadap penyelesaian permasalahan. Dugaan tersebut dibuktikan dengan memperoleh kebenarannya melalui percobaan yang berulang-ulang. Percobaan tersebut untuk menjawab dugaan sebelumnya. Setelah dugaan terjawab, mahasiswa dapat menyimpulkan hasil penyelesaian permasalahan dan menyajikannya dalam LKM untuk dikomunikasikan atau dipresentasikan dengan tujuan agar lebih memperjelas kebenaran yang telah diperoleh sehingga mahasiswa yang lain dapat mengoreksi hasil LKM masing-masing kelompok. Hasil akhir, mahasiswa dapat membuat soal sendiri mengenai grafik fungssi beserta penyelesaiannya. Dengan demikian, mahasiswa sangat aktif melakukan komunikasi selama proses pembelajaran menggunakan software graphmatica melalui pendekatan saintifik khususnya dalam komunikasi Matematika. Hasil analisis kemampuan komunikasi Matematika mahasiswa selama pembelajaran tersebut, dapat dilihat pada tabel 1. 
Numerical: Jurnal Matematika dan Pendidikan Matematika, Vol. 3 No. 2 Desember 2019, 95-104

Widiawati, Indah Widyaningrum

Tabel 1. Persentase Kemampuan Komunikasi Matematika Mahasiswa Secara Lisan dan Tulisan

\begin{tabular}{|c|c|c|c|}
\hline Indikator & Deskriptor & $\begin{array}{c}\text { Persentase } \\
\text { Komunikasi } \\
\text { Secara Lisan }\end{array}$ & $\begin{array}{c}\text { Persentase } \\
\text { Komunikasi } \\
\text { Secara Tulisan }\end{array}$ \\
\hline \multirow{3}{*}{$\begin{array}{l}\text { Kemampuan mengekspresikan } \\
\text { ide-ide Matematika melalui lisan, } \\
\text { tulisan, dan mendemonstrasikan } \\
\text { serta menggambarkannya secara } \\
\text { visual }\end{array}$} & $\begin{array}{l}\text { Mampu mengajukan } \\
\text { pertanyaan }\end{array}$ & $66,7 \%$ & - \\
\hline & $\begin{array}{l}\text { Mampu memberikan } \\
\text { gagasan }\end{array}$ & $83,3 \%$ & $100 \%$ \\
\hline & $\begin{array}{l}\text { Mampu menyelesaikan } \\
\text { permasalahan }\end{array}$ & - & $100 \%$ \\
\hline \multirow{3}{*}{$\begin{array}{l}\text { Kemampuan memahami, } \\
\text { menginterprestasikan, dan } \\
\text { mengevaluasi ide-ide Matematika } \\
\text { baik secara lisan maupun dalam } \\
\text { bentuk visual lainnya }\end{array}$} & $\begin{array}{l}\text { Mampu memahami } \\
\text { pertanyaan }\end{array}$ & - & $100 \%$ \\
\hline & menjawab & $100 \%$ & $100 \%$ \\
\hline & $\begin{array}{l}\text { Mampu memberikan } \\
\text { sanggahan }\end{array}$ & $83,3 \%$ & - \\
\hline \multirow{3}{*}{$\begin{array}{l}\text { Kemampuan menggunakan } \\
\text { istilah, notasi Matematika dan } \\
\text { struktur-strukturnya untuk } \\
\text { menyajikan ide, menggambarkan } \\
\text { hubungan dan model situasi }\end{array}$} & $\begin{array}{l}\text { Mampu menyebutkan } \\
\text { istilah Matematika }\end{array}$ & $100 \%$ & - \\
\hline & $\begin{array}{l}\text { Mampu menggunakan } \\
\text { notasi matematis }\end{array}$ & - & $100 \%$ \\
\hline & Mampu menyimpulkan & $100 \%$ & $100 \%$ \\
\hline \multicolumn{2}{|l|}{ Rata-rata Persentase } & $88,9 \%$ & $100 \%$ \\
\hline
\end{tabular}

Dari tabel 1 menunjukkan bahwa kemampuan komunikasi Matematika mahasiswa baik secara lisan maupun tulisan tergolong sangat baik. Hal ini dapat dilihat dari rata-rata persentase komunikasi secara lisan sebesar 88,9\% dan komunikasi secara tulisan sebesar 100\%. Walaupun demikian, kemampuan mahasiswa dalam mengajukan pertanyaan tergolong cukup baik dengan persentase sebesar 66,7\%. Sedangkan kemampuan mahasiswa dalam memberikan gagasan dan sanggahan sebesar 83,3\%. Ini berarti bahwa dengan adanya pendekatan saintifik dan penggunaan software graphmatica memberikan pengaruh yang positif dalam pembelajaran karena mahasiswa dapat menumbuhkan kemampuan komunikasi Matematikanya baik secara lisan maupun tulisan.

Proses pembelajaran menggunakan pendekatan saintifik dari mengamati grafik fungsi pada software graphmatica dan saling bertanya dalam penyelesaian permasalahan serta berpikir dengan mencoba-coba beberapa fungsi sampai menemukan ide penyelesaian. Pada akhirnya membentuk jejaring dengan menyimpulkan, menyajikan, dan mengkomunikasikannya. Selain itu, dengan membuat soal grafik fungsi sendiri dan penyelesaiannya menunjukkan bahwa mahasiswa telah memperoleh ide untuk menciptakan. Dari kegiatan mengamati sampai membentuk jejaring tersebut, mahasiswa mampu melakukan komunikasi Matematika seperti mengajukan pertanyaan, memberikan gagasan, menyelesaikan permasalahan, memahami pertanyaan, menjawab pertanyaan, memberikan sanggahan, menyebutkan istilah Matematika, menggunakan notasi matematis, dan menyimpulkan. Dengan demikian, kegiatan-kegiatan pada pendekatan saintifik merupakan kegiatan-kegiatan yang dapat memicu mahasiswa untuk selalu berkomunikasi karena mahasiswa diajak untuk aktif. Oleh karena itu, hasil belajar mahasiswa diperoleh rata-rata sebesar 83,5 dengan kategori sangat baik.Ini menunjukkan bahwa pembelajaran dengan pendekatan saintifik menggunakan software graphmatica pada materi grafik fungsi memberikan dampak yang baik bagi mahasiswa dari segi kemampuan komunikasi Matematika berujung ke hasil belajarnya. 
Kemampuan komunikasi matematika merupakan salah satu kemampuan yang sangat diharapkan ada pada peserta didik setelah peserta didik belajar matematika. Kemampuan komunikasi matematis diperlukan sejak dini melalui pembelajaran di kelas agar peserta didik bisa memecahkan masalah dan mengaplikasikan konsep matematika sebagai bekal hidup peserta didik masa sekarang dan masa yang akan datang. Temuan ini sesuai dengan hasil penelitian yang dilakukan oleh Nuralam [11]. Nuralam menemukan bahwa kemampuan komunikasi matematis tinggi cenderung mampu mencapai indikator mengekspresikan, mendemonstrasikan, menggambarkan, dan menginterpretasikan ide matematis serta kemampuan menggunakan istilah-istilah, notasi-notasi matematika, dan struktur-strukturnya untuk menyajikan ide matematis dan penelitian Arista [12] bahwa ide pendekatan saintifik mampu mendorong pembelajaran Matematika dalam konteks ilmiah dan kegiatan peserta didik.

\section{SIMPULAN DAN SARAN}

Berdasarkan hasil penelitian dan pembahasan, dapat disimpulkan bahwa kemampuan komunikasi Matematika mahasiswa selama diterapkan pendekatan saintifik menggunakan software graphmatica pada materi grafik fungsi tergolong sangat baik. Mahasiswa mempunyai kemampuan komunikasi Matematika baik secara lisan maupun tulisan. Hal ini dikarenakan proses pembelajaran dengan menggunakan software graphmatica melalui pendekatan saintifik menuntut mahasiswa untuk aktif dalam kegiatan-kegiatan pembelajaran seperti mengamati, menanya, menalar, mencoba, dan membentuk jejaring. Dengan kegiatan pembelajaran tersebut, hasil belajar mahasiswa pun dikategorikan sangat baik. Oleh karena itu, penggunaan software graphmatica melalui pendekatan saintifik memberikan pengaruh yang positif pada pembelajaran materi grafik fungsi karena dapat menumbuhkan kemampuan komunikasi Matematika mahasiswa. Dengan demikian, pembelajaran melalui pendekatan saintifik sangat tepat digunakan bagi mahasiswa agar kemampuan-kemampuan Matematikanya dapat tumbuh dan berkembang. Selain itu, penggunaan software graphmatica tidak hanya dapat digunakan untuk mata kuliah Aljabar, tetapi dapat juga digunakan untuk mata kuliah lain seperti Kalkulus.

\section{DAFTAR PUSTAKA}

[1] Ismail, B. Rahajeng, and R. Artiono, "Upaya Mengatasi Kesulitan Mahasiswa dalam Belajar Mata Kuliah Matematika Dasar di FMIPA UNESA Melalui Penggunaan Program Mathematica dan Penerapan Pembelajaran Kooperatif Tipe STAD," Didaktis, vol. 8, no. 2, pp. 18-25, Jun. 2009.

[2] M. Sabirin, A. Fitria, and S. Ningsih, "Profil Kemampuan Matematika Dasar Mahasiswa Program Studi Pendidikan Matematika Tahun Akademik 2013/2014," JPM LAIN Antasari, vol. 2, no. 2, pp. 29-42, Jan.-Jun. 2015.

[3] Y. L. Ningsih, "Kemampuan Pemahaman Konsep Matematika Mahasiswa Melalui Penerapan Lembar Aktivitas Mahasiswa (LAM) Berbasis Teori Apos Pada Materi Turunan," Edumatica, vol. 6, no. 1, pp. 1-8, Apr. 2016.

[4] D. Nopitasari, "Analisis Kemampuan Multi Representasi Matematis Berdasarkan Kemampuan Awal Matematis Mahasiswa," Pedagogy, vol. 2, no. 1, pp. 1-11, May. 2017.

[5] E. E. Muchlis, "Analisis Kesalahan Mahasiswa pada Materi Integral Lipat di Prodi Pendidikan Matematika FKIP Universitas Bengkulu," in Prosiding Seminar Matematika dan Pendidikan Matematika UNY, 2017, pp. 265-272.

[6] L. S. Wahyuniar and S. Widyawati, "Proses Berpikir Mahasiswa Dalam Menyelesaikan Soal Kombinatorial Berdasarkan Kecerdasan Logis Matematis," Numerical., vol. 1, no. 2, pp. 207-233, Dec. 2017. 
Numerical: Jurnal Matematika dan Pendidikan Matematika, Vol. 3 No. 2 Desember 2019, 95-104

Widiawati, Indah Widyaningrum

[7] H. Purwati and A. Andri Nugroho, "Analisis Kemampuan Komunikasi Matematis Mahasiswa dalam Menyelesaikan Masalah pada Mata Kuliah Program Linear," Jurnal Ilmu Pendidikan Matematika, vol. 1, no. 2, pp. 127-134, Okt. 2017.

[8] N. Nari, "Kemampuan Komunikasi dan Disposisi Matematis Mahasiswa pada Mata Kuliah Geometri," Ta'dib, vol. 18, no. 2, pp. 150-162, Dec. 2015.

[9] A. Susanto, Teori Belajar dan Pembelajaran di Sekolah Dasar. Jakarta: Kencana, 2013.

[10] Y. Yuniarti, "Pengembangan Kemampuan Komunikasi Matematis dalam Pembelajaran Matematika di Sekolah Dasar," Eduhumaniora, vol. 6, no. 2, pp. 109-114, Jul. 2014.

[11] N. Nuralam and E. Eliyana, "Penerapan Pendekatan Saintifik Terhadap Kemampuan Pemecahan Masalah Matematika di SMAN 1 Darul Imarah Aceh Besar," Jurnal Ilmiah Didaktika, vol. 18, no. 1, pp. 64-76, Aug. 2017.

[12] D. Arista Istikomah and P. Jana, "Kemampuan Pemahaman Konsep Matematis Mahasiswa Melalui Pendekatan Pembelajaran Saintifik dalam Perkuliahan Aljabar Matrik," in Prosiding Seminar Nasional Etnomatnesia, 2018, pp. 927-932.

[13] S. H. Nasution, "Pentingnya Literasi Teknologi Bagi Mahasiswa Calon Guru Matematika," Jurnal Kajian Pembelajaran Matematika, vol. 2, no. 1, Apr. 2018.

[14] A. Aziz and I. J. Suprayitno, "Eksperimentasi Metode Pembelajaran Brainstorming Terhadap Prestasi Belajar Riset Operasi Pokok Bahasan Program Linear," Jumal Kajian Pembelajaran Matematika, vol. 2, no. 1, pp. 14-18, Okt. 2018.

[15] Noor, Metodologi Penelitian. Jakarta: Kencana, 2017. 